\title{
The Paradigm of the General Principles of Good Governance as Examination Method of Indonesian Presidential Impeachment Based on the Perspective of Ethical Control
}

\author{
Nadir* \\ DOI: https://doi.org/10.22304/pjih.v7n2.a1
}

Submitted: April 1, 2020 | Accepted: July 7, 2020

\begin{abstract}
This study aims to reveal the paradigm of General Principles of Good Governance as a method of examination for Indonesian presidential impeachment based on the perspective of ethical control. This study employed the method of legal research. It was carried out to reveal principles and basis of (dogmatic or doctrinal) philosophy of positive law. In addition, the study is legal discovery in-concreto that is feasible to be applied to resolve a certain legal case. This study exposes that one of the legal reasons for the termination of the President of Indonesia is despicable deeds. It is determined as an act of President that degrade human characters. Hermeneutically, the meaning of "despicable deeds" may cover criminal acts and ethical actions. Therefore, the meaning of "despicable deeds" in this study is limited into acts of ethics infringement related to the General Principles of The Good Governance. The President can be terminated from the office when there is a violation to the General Principles of the Good Governance since the principles are the ethical principles of government. The principles contain honesty, accuracy, purity, balance, and legal certainty. These principles are the items that bring solution and reference for the House of Representatives (DPR) and the People's Consultative Assembly (MPR) and the Constitutional Court. Theoretically, there is no norm, either of the 1945 Constitution or of other regulations, which limit the interpretation of "despicable acts" as a reflection of the acts of the President to be classified into ethical conducts. Therefore, the application of the General Principles of Good Governance as method of examination for the presidential impeachment is a new paradigm from the perspective of ethical control in Indonesia.
\end{abstract}

Keywords: ethical control, general principles of good governance, presidential impeachment.

\section{Paradigma Penerapan Asas-Asas Umum Pemerintahan Yang Baik (AUPB) sebagai Batu Uji Pemberhentian Presiden Indonesia berdasarkan Perspektif Pengawasan Etik}

PADJADJARAN Journal of Law Vol. 7 Number 2 Year 2020 [ISSN 2460-1543] [ISSN 2442-9325]

Lecturer of The Faculty of Law, University of Madura, Jln. Raya Panglegur KM. 3,5 Pamekasan Madura, S.H. (Universitas Widyagama Malang), M.H. (PPS Universitas Widyagama Malang), Dr. (Universitas Brawijaya), mh_dira@yahoo.co.id. 


\begin{abstract}
Abstrak
Tujuan penelitian ini untuk menemukan Paradigma Pemberhentian Presiden Indonesia dengan Batu Uji Asas-Asas Umum Pemerintahan Yang Baik dalam Perspektif Pengawasan Etik. Metode penelitian ini adalah penelitian hukum (legal research), yaitu: suatu penelitian yang dikerjakan dengan tujuan untuk menemukan asas dan dasar falsafah (dogma atau doktrin) hukum positif, di samping itu penelitian berupa usaha penemuan hukum in concreto yang layak diterapkan untuk menyelesaikan suatu perkara hukum tertentu. Hasil penelitian ini menunjukkan bahwa salah satu alasan hukum pemberhentian Presiden Indonesia adalah perbuatan tercela sebagai refleksi perbuatan merendahkan martabat Presiden. Secara hermeneutik makna "perbuatan tercela" dapat dikualifisir masuk ke dalam perbuatan dari segi pidana dan perbuatan dari segi etika, oleh karena itu makna "perbuatan tercela" dalam penelitian ini dapat dikualifisir masuk ke dalam perbuatan melanggar etika, sehingga masuk ke dalam AUPB dan Presiden dapat diberhentikan dalam masa jabatannya. AUPB dimaksud adalah asas etis pemerintahan yang terkandung dalamnya adalah asas kejujuran, kecermatan, kemurnian, keseimbangan, dan kepastian hukum. Asas ini masuk ke dalam AUPB yang dapat dijadikan solusi kaidah penuntun dan rujukan bagi DPR-MPR dan Mahkamah Konstitusi Republik Indonesia. Secara teoritis tidak ada batasan norma baik norma hukum yang tertuang di dalam UUD RI Tahun 1945 maupun norma hukum yang ada di luar UUD RI Tahun 1945 melarang interpretasi "perbuatan tercela" sebagai refleksi perbuatan merendahkan martabat Presiden masuk ke dalam perbuatan melanggar etika, sehingga penerapan Asas-Asas Umum Pemerintahan Yang Baik (AUPB) sebagai batu uji pemberhentian Presiden merupakan paradigma baru dalam perspektif pengawasan etik di Indonesia.
\end{abstract}

Kata Kunci: asas-asas umum pemerintahan yang baik, pemberhentian presiden, pengawasan etik.

\title{
A. Introduction
}

On May 21, 1998, Indonesia experienced the downfall of the President Suharto's New Order regime. It is an empirical fact that an authoritarian, despite maximum effort to maintain power behind legitimacy of constitution and hegemony of politics, law, and bureaucracy will finally end. In the aftermath, the idea of reformation emerged in fields of politics, legal, economy, social, and government. The event may equal to the movement of the notions of Rationalism, Romanticism, and Aufklarung. The movement was supported and organized by the middle class. It led to political and social revolutions. The results were two famous revolutions: the United States of America in 1776 and the French Revolution in 1789. The event has shaped the understanding of democracy. ${ }^{1}$

The situation and the condition of the two major revolutions are parallel to the situation and the conditions of the 1999 Indonesia. It is a golden year for Indonesian civil society pro-reform movement. This is marked by four amendments

Nadir, "Dilematika Putusan Mahkamah Konstitusi vs Kekuatan Politik dalam Impeachment Presiden", Jurnal Konstitusi, Vol. 9, No. 2, 2012, p. 334. 
The Paradigm of the General Principles of Good Governance as Examination Method of Indonesian Presidential Impeachment Based on the Perspective of Ethical Control

to the 1945 Constitution from 1999 to 2002 that has straightened the Indonesian version of Presidential system as the rule of law state system of Indonesia.

Amendment is conducted commonly and reasonably in many states of the world to perfect system of government. A system may be obsolete or there are revolutions and reforms requiring major changes to constitution. A constitution is a state's main element and source of law. In general, a constitution underlies state's constitutional life. In addition, constitution can be applied comprehensively as a rule of law and moral to solve political and social conflicts in life of nation and state, in this case: Indonesia. ${ }^{2}$

In Indonesia, the People's Consultative Assembly (Majelis Permusyawaratan Rakyat) may impeach President and/or Vice President during term of office. The impeachment can be realized based on the proposal made by the House of Representatives. The reasons and the conditions for the impeachment are confirmed in Article 7A and 7B of the 1945 Constitution. In Article 7A, as the main parameter of impeachment, the President and/or Vice President may be dismissed from office by the MPR based on a proposal from the DPR, either when proven guilty of violating the law by betrayal of the state, of corruption, of bribery, of any other felony, or because of disgraceful behavior, as well as proven no longer to fulfill the conditions as President and/or Vice President. Furthermore, Article 10 paragraph (3) of Law Number 24 Year 2003 concerning the Constitutional Court provides confirmation of the types of violations of the law referred to in Article $7 \mathrm{~A}$ of the 1945 Constitution. Despicable acts are actions which can demean the President and / or the Vice President.

The legal perspective on disgraceful acts as the realization of the President's degrading actions still raises multiple interpretations academically. This is especially true from the perspective of control of ethics on the President as the organizer of the state government. This study is in a position to see that the legal position of misconduct meets the qualifications for testing based on the General Principles of Good Governance.

According to Indroharto, the existence of the General Principles of the Good Governance is very important. It also includes the function of the General Principles of the Good Governance as the paradigm in Presidential impeachment due to several reasons. ${ }^{3}$ They are among others as follows.

1. The General Principles of the Good Governance is considered a part of the applicable positive law.

2. The General Principles of the Good Governance is norms of state administration.

Ibid.

Indroharto, Usaha Memahami Undang-Undang tentang Peradilan Tata Usaha Negara, Jakarta: Pustaka Sinar Harapan, 1991, p. 147. 
3. The General Principles of the Good Governance can be foundation to file a lawsuit

4. The General Principles of the Good Governance can test tools to assess validity of state administration's decision.

5. The General Principles of the Good Governance will not lose its power in its development because it can be explored in people's life.

The concept of applying the General Principles of Good Governance as the basis of presidential impeachment is a juridical instrument or a test tool to determine president's despicable act in the definition of President's actions that demeans dignity as the head of state and government. This is performed to determine the qualifications whether certain president's acts are contrary to the norms of the General Principles of Good Governance so that the President can be impeached during the term of office.

The reasons and the provisions for Presidential impeachment according to Article 7A of the 1945 Constitution, especially on the term "disgraceful act", have caused problems, philosophically, juridical, theoretically, and socio-politically. It does not reflect ethical values to state administrators.

This study is a legal research. It was undertaken to discover the principles and philosophical basis (either dogma or doctrine) of positive law. In addition, this study is an attempt to find legal in-concreto to resolve a particular legal case. Therefore, this study can be called a dogmatic study, or commonly known as doctrinal research. ${ }^{4}$

This study uses a theoretical, statute, conceptual, and philosophical approach. Types and sources of legal materials in this study include primary, secondary, and tertiary legal materials. The method of gathering legal material is done through identification and tracking relevant laws and regulations. The findings are then analyzed using theoretical instruments. The results are presented in the form of descriptive analytic or prescriptive analytic.

\section{B. A Brief History of the Development of the General Principles of Good Governance}

De Monchy Commission Report in the Netherlands first introduced the term "the General Principles of Good Governance". It refers to efforts of increasing legal protection for people against government. Van der Grinten then used the principle in the report on Administrative Courts and judicial violations of disciplinary rules in company organizations. ${ }^{5}$

Soetandyo Wignjosoebroto, 1974. "Hukum dan Metode-metode Kajiannya dan Penelitian Hukum: Sebuah Tipologi", Majalah Masyarakat Indonesia Tahun ke-1 No. 21974.

5 Amrah Muslimin, Beberapa Asas dan Pengertian Pokok Tentang Administrasi dan Hukum Administrasi, Bandung: Alumni, 1985, p. 145. 
The Paradigm of the General Principles of Good Governance as Examination Method of Indonesian Presidential Impeachment Based on the Perspective of Ethical Control

The purpose of the general principles regarding good governance is not only to applied in certain cases, but it also covers general subjects of administration. Muslimin emphasizes that, in the state administration court, the General Principles on Good Governance have been applied to assess whether the decrees issued were against the principles or not. ${ }^{6}$

The General Principles of Good Governance are predicted to increasingly infiltrate positive law. Wiarda gives a more structured breakdown of elements of the principles. They are listed in the jurisprudence of administrative judges and general court judges as follows. ${ }^{7}$

1. The principle of honesty (Fair play)

2. The principle of accuracy (Zorgvuldigheid)

3. The principle of purity in purpose (Zuiverheid van oogmerk)

4. The principle of balance (Evenwichtigheid)

5. The principle of legal certainty (Rechts zekerheid)

According to history of regulation, the desire to incorporate the General Principles of Good Governance into concrete rule of law has been pioneered actually since 1948. Of several drafts of administrative justice that were proposed at that time, according to Hamidi, only Soemitro's concept which lists the Principles as one of the elements to fill a lawsuit as contained in Article 14 point e, but this concept does not continue. ${ }^{8}$

In 1986, the faction of armed forces in the House of Representatives reproposed Soemitro's idea in a discussion of the Draft of the Administrative Judicial Law. The draft was legalized as the Law Number 5 of 1986 . However, no even single article that explicitly regulates the existence of the General Principles of Good Governance. Implicitly, Points b and c, namely the principle of prohibition of abusing authority and the principle of prohibition of acting not arbitrarily, have a close reference. ${ }^{9}$

In Indonesia, experts provide various definitions to the principles of state government. The Law Number 30 of 2014 on Government Administration standardizes the term "General Principles of Good Governance". Ridwan argues that the Principles, in addition to language factors, were emerged due to historical factors that lie behind it. This is because AAUPL grew out of a long historical process. The principles are a discourse that is studied and developed by academicians. They develop different formulations and interpretations. Hence, the concept or definition of the context of language and history is needed.

Ibid.

Ibid.

Jazim Hamidi, Penerapan Asas-Asas Umum Pemerintahan Yang Layak (AAUPL) di Lingkungan Peradilan Administrasi Indonesia, Bandung: Citra Aditya Bakti, 1999, p. 133.

Ibid., p. 133. 
According to Hamidi, the definition of the General Principles of Good Governance is as follows. ${ }^{10}$

1. The Principles are ethical values that live and develop in the legal environment of the State Administration.

2. The Principles function as a guideline for state administration officials in carrying out their functions. It is a test tool for administrative judges in assessing state administrative actions (which are tangible), and as a basis to filing lawsuit for parties.

3. The Principles are still unwritten, abstract, and can be explored in the practice of life in society.

4. Some of the Principles have been written legal principles that are scattered in various positive regulations. Although some of the principles have been changed to written legal principles, their nature remains as legal principles.

According to Van Wijk, Konijnenbelt, and Ten Berge, the Principles in the legal system is established as an unwritten law. Syafrudin adds that from the perspective of legal science, the principles and norms are clearly different. Principle is a very general and abstract thought. It can be interpreted as an idea or concept that has no sanctions. Norm is a concrete legal rule as a translation of principles or ideas that contain binding sanctions. Principles and convention are different and cannot be used interchangeably. ${ }^{11}$

According to Hadjon, the General Principles of Good Governance consist of the principles of (1) equality, (2) trust, (3) legal certainty, (4) accuracy, (5) motivation, (6) detournement de pouvoir to abuse of authority, and (7) prohibition of arbitrary actions. $^{12}$ In Indonesia, the General Principles of Good Governance are placed in legal norms that are scattered in several laws and regulations. It is still principles even though it has been formalized.

\section{The New Paradigm of Presidential Impeachment Based on the General Principles of Good Governance}

President, as the head of state and government, has a very extensive power. The power includes the position as the commander-in-chief of the armed forces and the authorities to appoint public officials; to format and to change state's institutions (including departments); to make agreements, to declare war, to give amnesty, abolition, clemency, and rehabilitation; to give rewards of service, to declare the state of danger; etc.

\footnotetext{
10 Jazim Hamidi, Penerapan Asas-Asas Umum Penyelenggaraan Pemerintahan Yang Layak (AAUPL) di Lingkungan Peradilan Administrasi Indonesia, Bandung: Citra Aditya Bakti, 1999, p. 24.

11 Ridwan H.R., Hukum Administrasi Negara, Jakarta: RajaGrafindo Persada, 2006, p. 250.

12 Philipus M. Hadjon, (et.al), Pengantar Hukum Administrasi Indonesia, Yogyakarta: Gajah Mada University Press , 2011, p. 270.
} 
The Paradigm of the General Principles of Good Governance as Examination Method of Indonesian Presidential Impeachment Based on the Perspective of Ethical Control

The President of the Republic of Indonesia has authorities to make several forms of legislation and regulation. The President also has a right to involve in the making process of legislation, emergency law, government regulation, and presidential regulation. The authorities are attached to the President based on Article 4 section (1) of the 1945 Constitution, the power of the executive branch. ${ }^{13}$

Manan argues that President's power is indeed very broad and is not explained comprehensively in the 1945 Constitution. ${ }^{14}$ Nevertheless, President's power is not unlimited as explained in the General Explanation of the 1945 Constitution prior to its amendment. The Explanation states that the President's power is not unlimited. ${ }^{15}$ To balance president's power, a supervisory mechanism is established. To be clear, the mechanism may lead to an impeachment process. This once happened to President Soekarno and President Abdurrahman Wahid. ${ }^{16}$ In fact, the impeachment of the two former Presidents happened before the amendments to the 1945 Constitution. Both Presidents were impeached by the MPR for the violation to the 1945 Constitution and/or the Broad Outlines of the Nation's Direction (GBHN -Garis-garis Besar Haluan Negara) and their Accountability Reports were rejected by the MPR. ${ }^{17}$

Impeachment is not a mechanism to overturn outcome of a legitimate election or a way for public to judge a leader arbitrarily. In other words, hate or dislike is not sufficient grounds to impeach a president. ${ }^{18}$ According to Prakash, many people assume that impeachment is the only means of removing a President and that the constitution grants an implicit reference to impeachment. ${ }^{19}$

According to Syafie, one of the principles of government is the ethical principle in which the principle teaches us that the government cannot be separated from moral principles. Therefore, Indonesia always urges the implementation of the Guidelines for the Implementation and Application of Pancasila. On the other hand, each religion competes to convey moral teaching. The government is not far apart from moral ethics, but it is a mandate of God, which must be accounted for in the hereafter. $^{20}$

According to Koesoemahatmadja (1981), the Principles of Ethical Government include honesty, accuracy, purity, balance, and legal security. On the other hand,

\footnotetext{
13 Rahayu Prasetianingsih, "Menakar Kekuasaan Presiden dalam Pembentukan Peraturan Perundang-undangan menurut Undang-Undang Dasar 1945", Padjadjaran Jurnal of Law, Vol. 4, No. 2, 2017, pp. 263-280.

14 Bagir Manan on Rusdianto, "Proses Impeachment Presiden Dalam Konstitusi Negara-Negara Modern: Studi Perbandingan dengan Mekanisme Impeachment di Amerika Serikat dan Korea Selatan”, Jurnal Hukum, Vol. 19 , No. 19,2010 , p. 1.

lbid. p. 117.

lbid., pp. 109-110.

Ibid.

18 Michael A. Genovese, "Impeachment Revisited in the Age of Trump", Book Review Essay, Presidential Studies Quarterly Vol. 48, Issue 3, 2018, p. 615.

19 Saikrishna Prakash and Steven D. Smith, "How to Remove a Federal Judge", Yale Law Journal, Vol. 116, Number 1, 2006, p. 72.

20 Inu Kencana Syafie, Sistem Pemerintahan Indonesia, Jakarta: Rineka Cipta, 2011, pp. 71-72.
} 
Van Polje argues that principles of ethics include legal security, balance, equality in making decisions, acting prudently and carefully, having motivation for every decision, not abusing authority, carrying out duties sincerely, not acting arbitrarily, meeting the expectations of people, disproving the consequences of the decision to cancel something, and protecting the private way of life of its citizens. ${ }^{21}$

Based on the principles as previously described, the legal definition of despicable acts can be qualified into the legislation because the principles contain legal certainty and accuracy. Therefore, President can be impeached based on the General Principles of the Good Governance. It is a new paradigm for presidential impeachment.

If the ethical moral is enforced and upheld as well as taking it precedence over the norm of law, then the rule of law will be followed. Ethics enforcement should be higher than the norm of law because ethics affects. The problem in Indonesia is that the norm of law is not even close to the ethical-moral so that there is a "legal norms without meaning". ${ }^{22}$

The government has extraordinary authorities that consist of two types. First, prior authority carries out the decisions taken without asking for prior approval from the agency or any individual. Second, ex officio authority means that all decisions taken due to position (especially based on oath of office) that cannot be opposed by anyone and they who against the authority are subject to criminal sanctions (for example Article 160, 161, 211, 212, 216 of the Criminal Code).

In this case, public officials have extraordinary authority to decide any aspects related to their daily tasks. Therefore, actions of government officials must always be monitored to prevent arbitrariness. ${ }^{23}$ However, the freedom of action is not unlimited. The freedom limited by the General Principles of Good Governance. It is expected that there is no abuse of power. ${ }^{24}$

To oversee the government actions or deeds, the General Principles of Good Governance must be used as an examination tools for presidential impeachment based on the perspective of ethics. The General Principles of Good Governance in Indonesia has not yet positioned in the 1945 Constitution so that it does not have formal legal force. A despicable disgraceful act can be viewed as a violation of the General Principles of Good Governance.

According to the theory of hermeneutics, a despicable act may be viewed as a legal reason for impeachment. Therefore, the meaning of "despicable deeds" in this study is determined as an ethical violation. Therefore, it can be included in the

Paimin Napitupulu, Pelayanan Publik dan Customer Satisfaction. Bandung: Alumni, 2014, p. 15.

Nadir (et.al), "Philosophical Validity, Theoretical, Normative and Empirical Paradigm of General Principles of Good Governance (AUPB) as a Review of Presidential Impeachment", Brawijaya Law Journal, Vol. 4, No. 1, 2017, p. 110

Ibid.

24 Ansori Lutfil, "Diskresi dan Pertanggungjawaban Pemerintah dalam Penyelenggaraan Pemerintahan”, Jurnal Yuridis, Vol. 2, No. 1, 2015, p. 134. 
The Paradigm of the General Principles of Good Governance as Examination Method of Indonesian Presidential Impeachment Based on the Perspective of Ethical Control

General Principles of Good Governance and the President can be impeached based on the General Principles of Good Governance as the examination tool. The principles consist of honesty, accuracy, purity, balance, and legal security.

Abu Zaid argues that the basic problem of hermeneutics is the problem of interpreting texts in both the form of historical texts and religious texts. Therefore, problems may be more complicated beyond the basic nature of text. The most important of the many problems is that hermeneutics focuses on its correlation with interpreter of text. ${ }^{25}$ According to Hamidi, the basis for a large understanding of the theory of hermeneutics can be understood hermeneutics as the basis for philosophical philosophy of law and as a method of interpretation. ${ }^{26}$

The application of the General Principles of Good Governance as an examination tool of Presidential Impeachment based on the perspective of ethical control can be considered as a solution. The tem despicable acts formulated in Article 7A of the 1945 Constitution can be portrayed based on ethics. In addition, the application of the Principles does not contradict the 1945 Constitution. Theoretically, there is no clear definition on legal norms (the 1945 Constitution) and other norms that prohibit the interpretation of "despicable acts" as any degrading acts of President to be classified as ethical misconduct. Therefore, the application of the Principles can be implemented based on ethical control.

The paradigm of the General Principles of Good Governance as the basis for the impeachment of President is a new idea in the realization of the Indonesian Constitution. According to Ihalauw, every theory or model is built on certain paradigms. A paradigm is a set of assumptions, both explicit and implicit, which form basis of scientific ideas. Assumptions need to be made because human capacity is very limited to be able to reap complex and dynamic realities. ${ }^{27}$

The presidential impeachment by using the Principles as a tool is, inevitably, a new paradigm because no state has used the Principles as a test tool to impeach President based on the perspective of ethical control. All legal reasons for presidential impeachment are regulated in state constitution. In general, all reasons in 1945 Constitution also include criminal offenses. States that use criminal acts as legal reasons for presidential impeachment place more emphasis on the paradigm because of enormous violations, when compared to the ethics of violations. However, all legal reasons in a state's constitution are the function of control to president in carrying out duties and authorities so that there is no abuse of authority.

25 Nashr Hamid Abu Zaid, Hermeneutika Inklusif: Mengatasi Problematika Bacaan dan Cara-Cara Pentakwilan atas Diskursus Keagamaan, Jakarta: International Center For Islam and Pluralism, 2004, p. 3.

26 Jazim Hamidi, Revolusi Hukum Indonesia: Makna Kedudukan dan Implikasi Hukum Naskah Proklamasi 17 Agustus 1945 dalam Sistem Ketatanegaraan RI, Jakarta: Kon-Press, 2006, p. 12.

27 John J.O.I. Ihalauw, Konstruksi Teori: Komponen dan Proses, Jakarta: Grasindo, 2008, p. 144. 
The legal objective paradigm must create justice, certainty, and security. It also must be beneficial for legal subjects as people with rights and obligations. Thus, justice becomes a measure of balance between rights and obligations in legal subjects because it puts everything in its place. Whereas certainty and security provide a measure of the clarity of legal status for legal subjects so that justice, certainty, security, and benefits are harmonized. The decision of the Constitutional Court in applying the Principles as a review tool for presidential impeachment must create a paradigm of legal objectives.

In trial of the Constitutional Court, the application of the Principles by the Constitutional Court Judges can be interpreted based on the provisions of Article 5 and 10 of Law Number 48 of 2009 on Judicial Power. Constitutional Judges must explore, follow, and understand the legal values and sense of justice that live within the society. The Courts are not allowed to refuse to examine, hear, and decide case filed under the pretext that the law does not exist or is unclear but is obliged to examine and try it.

The involvement of the Constitutional Court as a judicial institution in the presidential impeachment process is to determine whether the president is proven to have violated the law. This is in accordance with Article 7A of the 1945 Constitution. Furthermore, Article 7B of the 1945 Constitution is very democratic in the presidential impeachment process. This is different from the case of presidential impeachment that occurred with President Abdurrahman Wahid (Gusdur) that did not go through a judicial institution.

In the US, the Constitution establishes general principles that control procedural aspects of impeachment, giving the authority of impeachment to the House of Representatives. The Constitution also authorizes the Senate to try impeachment. Both the Senate and the House of Representatives can design procedures for applying these general principles in the matter of impeachment. This short report provides a brief review of the impeachment process, which reflects the role of the House of Representatives and the Senate during the investigation and trial of impeachment. ${ }^{28}$

For the judges of the Constitutional Court, it is reasonable and fundamental to apply the Principles as a basis for assessing whether acts of executive contradict the Principles or not. However, the Principles are one element that can be used to judge whether executive action is legitimate. To apply the Principles as a review for the dismissal of the President, there is a long way to go for judges of the Constitutional Court that can be done technically through induction and reduction of legal grounds.

The function of the Principles is more to fulfill the size or the guidelines for legality of a government action, while good governance is more towards guiding

28 T. J. Halstead, "An Overview of the Impeachment Process", CRS Report for Congress Received through the CRS Web, Issue 20, 2005, p. 1. 
The Paradigm of the General Principles of Good Governance as Examination Method of Indonesian Presidential Impeachment Based on the Perspective of Ethical Control

behavior (officials) of the government (broad meaning) and other related parties in managing a good country. The Principles are made as a guideline or measurement tool for the government in taking legal actions. They must not be violated because the Principles some have become the norm and some others remain as principles that are spread in people's lives.

Achmad Ali further explains that dispute is not settled by the rule of law contained in laws, customs, treaties, jurisprudence, doctrine, and religious law. Dispute resolution is "the rule of law born from the judgment of judges." ${ }^{29}$

For instance, the case of President Clinton is the first impeachment since President Johnson in 1868. The impeachment emerged almost unexpectedly from a judicial proceeding. Two constitutional questions ran in the event: the scope of impeachment and the exposure of a Presidential impeachment. A similar case, the Watergate affair, received extensive scrutiny. The case led to President Nixon's resignation in 1974. In impeachment, the academic consensus at the beginning of the process was that violations, according to the Constitution, include betrayal, bribery, or high crime, and other minor violations. The latter term describes a category of serious violations whose definition is unclear. ${ }^{30}$

Althuser illustrates that the Judicial Committee of the House of Representatives voting in 1974 to approve the articles of impeachment against President Nixon followed by both parties. There were seven out of seventeen Republicans in the Committee who elected one or more articles. Honorary Committee of the House of Representatives in 1998 was divided sharply. Almost all Republicans supported all articles of impeachment. On the other hand, all Democrats opposed it. Polls and the results of the Congressional elections after the two impeachments show that the public saw the 1998 Clinton impeachment as more political and less responsible than the Nixon impeachment in 1974. The Committee's hearing was bipartisan in nature. Three aspects of the 1974 Committee's impeachment process seemed to have pushed for a less divisive process. ${ }^{31}$

Based on the perspective of the theory of legal source, the General Principles of Good Governance are "fundamental norms". It is in the formation of legal norms. Thus, the Principles can be classified as a source of material law that can bring up legal norms. For example, one of the principles is balance and fairness. The principle is reflected fundamentally in Pancasila as the source of all sources of state law which become the basic norm.

The Netherlands detailed the Principles (algemene beginselen van behoorlijk bestuur). On the other hand, Anglo-Saxon countries form the principle of "good

29 Achmad Ali, Menguak Tabir Hukum: Suatu Kajian Filosofis dan Sosiologis, Jakarta: Chandra Pratama, 1996, p. 141.

30 Joseph Isenbergh, "Impeachment and Presidential Immunity from Judicial Process," Yale Law and Policy Review, Vol. 18, Issue 53, 1999, p. 53.

31 Fred H. Altshuler, "Comparing the Nixon and Clinton Impeachments", Hastings Law Journal, Vol. 51, Issue 4, 2000, p. 745. 
governance" as a general and abstract rationale. The Principles are the normative of a philosophy of life that gives direction or insight to carry out good governance.

The Netherlands specifies the General Principles of Good Governance (algemene beginselen van behoorlijk bestuur) and in Anglo Saxon countries formed in the principles of "good governance" in which the General Principles of Good Governance are a common and abstract rationale as a normative emission of a philosophy of life that gives direction or views to carry out governance properly.

The General Principles of Good Governance, according to Purbopranoto, include: ${ }^{32}$
(1) legal security
(2) proportionality
(3) equality
(4) carefulness
(5) motivation
(6) non misuse of competence
(7) fair play
(8) reasonable or prohibition of arbitrariness
(9) meeting raised expectation
(10) undoing the consequences of annulled decision
(11) protecting the personal way of life
(12) saliently
(13) public service

The thirteen principles focus mainly on judiciary values. They rely on the internalization of justice in the process of government administration and the utilization of the judiciary in handling administrative problems or disputes. ${ }^{33}$ Hadjon and friends pointed out that the General Principles of Good Governance must also be seen as unwritten legal norms. The government must always obey them, despite the precise definition of the General Principles of Good Governance for each situation is exceptional. Therefore, the general principles of good governance are unwritten legal principles. $^{34}$

The Principles can be seen as unwritten legal rules, indeed. It is especially in the making process of state administrative decisions. There is no fundamental contradiction between the Principles, which are not written and the written law. However, the Principles are well formulated as principles. ${ }^{35}$

\footnotetext{
32 Kuntjoro Purbopranoto, Beberapa Catatan tentang Hukum Tata Pemerintah dan Peradilan Administrasi Negara, Bandung: Alumni, 1985, p. 29.

33 Wahyudi Kumorotomo, Etika Administrasi Negara, Jakarta: RajaGrafindo Persada, 2001, p. 287.

34 Philipus M. Hadjon, (et.al), Pengantar Hukum Administrasi Indonesia, Yogyakarta: Gadjah Mada University Press, 1993, p. 265.

$35 \quad$ Ibid., p. 268.
} 
The Paradigm of the General Principles of Good Governance as Examination Method of Indonesian Presidential Impeachment Based on the Perspective of Ethical Control

President as head of state and government with very broad authorities can issue policies in normal or abnormal conditions. In an abnormal condition (emergency), President can issue policies to fill the legal vacuum and must not conflict with the laws and regulations and be in accordance with the General Principles of Good Governance. If the policy results in degrading the president's dignity that is considered violation of ethics included in the Principles, then President can be impeached.

The examination of government, or state administration officials, policies is a new idea in the field of state administration law. This idea has started to be developed since the middle of the $20^{\text {th }}$ Century. ${ }^{36}$ An examination of government policies or state administration officials by a judicial institution shows that judicial branch may interfere the executive power. Before the $20^{\text {th }}$ Century, the idea of the interference of one branch of power over another branch was impossible because, at that time, the dominant thought was the idea of the strict separation of powers between the three branches of state power. ${ }^{37}$

\section{The Legal Implications of the Implementation of the General Principles of Good Governance as Examination Method of Indonesian Presidential Impeachment based on the Perspective of Ethical Control}

Implementation of the General Principles of Good Governance in the Indonesian government system can run well and smoothly with the support of good and stable administration. Administration is related closely to management and implementation of overall organizational activities. Administration affects organization in the achievement of objectives. ${ }^{38}$

In the Netherlands, the Principles are defined as the principle of validity. In government administration, they are the hallmark of good governance. According to UNDP, the characteristics of good governance include participation, rule of law, transparency, responsiveness, serving each stakeholder, consensus orientation, equity, effectiveness and efficiency, accountability, and strategic vision. ${ }^{39}$ According to Kusdarini, the Principles are needed so that actions taken by the state administration apparatus do not injure citizens. ${ }^{40}$

36 Kuntjoro Purbopranoto, Beberapa Catatan tentang Hukum Tata Pemerintah dan Peradilan Administrasi Negara, Bandung: Alumni, 1985, p. 28

37 Hotma P. Sibuea, Asas Negara Hukum, Peraturan Kebijakan dan Asas-Asas Umum Pemerintahan Yang baik, Jakarta: Erlangga, 2010, p. 142.

38 Muhamad Azhar, "Relevansi Asas-Asas Umum Pemerintahan Yang Baik Dalam Sistem Penyelenggaraan Administrasi Negara", NOTARIUS, $8^{\text {th }}$ Edition, No. 2, 2015, p. 278.

39 Djodi Suranto, "The Implementation of Good Governance General Establishment and Application in The Formation of Good Governance Implementation in Indonesian National Army", Jurnal Hukum dan Peradilan, Vol. 6, No. 1, 2017, p. 135.

40 Eny Kusdarini, "Asas-asas Umum Pemerintahan yang Baik pada Produk Hukum Perizinan Investasi Pemerintah Daerah", Jurnal Hukum IUS QUIA IUSTUM, Vol. 24, No. 4, 2017, pp. 663-688. 
Implications are "indirect effects or legal consequences" of the application of a theory or legal principles in the legal field. Therefore, this study defines the legal implications of the implementation of the general principles of good governance as examination method of Indonesian presidential impeachment based on the perspective of ethical control as follows. ${ }^{41}$

1. Juridical implications arising from the General Principles of Good Governance can be used as a source of reference and guidelines for presidential impeachment if the acts are in the form of beschikking, regeling, or materialism classified as legal reasons for disgraceful acts as a reflection of the President's degrading actions that violate ethics.

2. The values of the General Principles of Good Governance can be used as reference sources and guiding rules for the DPR and the MPR. For the Constitutional Court, the Principles can be examination method to test the validity of presidential impeachment.

3. The values of the General Principles of Good Governance in the administration of the Republic of Indonesia can be classified as a source of material law. On the other hand, the formal law does not accommodate the General Principles of Good Governance in the 1945 Constitution. However, despicable acts can be interpreted as acts of violating ethics that degrade the President.

4. The application of the General Principles of Good Governance as a method of examination for Presidential Impeachment implies careful action and legal certainty as parts of ethical values. Therefore, President's acts or deeds do not harm the will of the people in general or do not degrade the Government.

5. The application of the General Principles of Good Governance requires the extension of the meaning of 'despicable deeds' as a realization of ethical violations. It must imply the President's low dignity and the creation of prudential principles and precision in government.

6. The General Principles of Good Governance is a review to impeach President. It implicates the expansion of functionality of the control of the DPR and the MPR against the executive board (the President) and the creation of the principles of honesty and austerity in governance and presidential system of Indonesia.

\section{E. Conclusion}

Hermeneutically, the meaning of despicable act can be defined as criminal actions and unethical conducts. Therefore, this study defines the meaning of despicable act as an ethical violation so that it is covered by the General Principles of Good Governance. Based on the perspectives, the President can be impeached during term of office. The General Principles of Good Governance is the ethical principles of government that consist of the principles of honesty, accuracy, purity, balance,

$41 \quad$ Nadir (et.al), op.cit, p. 113. 
The Paradigm of the General Principles of Good Governance as Examination Method of Indonesian Presidential Impeachment Based on the Perspective of Ethical Control

and legal certainty. These principles are considered as the General Principles of Good Governance, which can be used as guiding rule and references by the DPR, the MPR, and the Constitutional Court to impeach President during term of office if the President violates one of the principles. Theoretically and normatively, there is no comprehensive definition to the norms, either to legal norms, which are contained in the 1945 Constitution and other law and regulations. Therefore, despicable acts can be interpreted as acts of violating ethics that degrade the President. Overall, the application of the General Principles of Good Governance as a method of examination for presidential impeachment is possible. It is a new paradigm and is undoubtedly applicable in ethical supervision and control of the President.

\section{References}

\section{Books}

Achmad Ali, Menguak Tabir Hukum: Suatu Kajian Filosofis dan Sosiologis, Chandra Pratama, Jakarta, 1986.

Amrah Muslimin, Beberapa Asas dan Pengertian Pokok Tentang Administrasi dan Hukum Administrasi, PT. Alumni, Bandung, 1985.

Bagir Manan, Lembaga Kepresidenan, Revisied, FH UII Press, Yogyakarta, 2006.

Echols, John M. and Hassan Shadily, Kamus Inggris Indonesia, Gramedia, Jakarta, 2000.

Hotma P. Sibuea, Asas Negara Hukum, Peraturan Kebijakan dan Asas-Asas Umum Pemerintahan Yang Baik, Erlangga, Jakarta, 2010.

Inu Kencana Syafie, Sistem Pemerintahan Indonesia, edisi revisi, Rineka Cipta, Jakarta, 2011.

Indroharto, Usaha Memahami Undang-Undang tentang Peradilan Tata Usaha Negara, Pusataka Sinar Harapan, Jakarta, 1991.

Jazim Hamidi, Penerapan Asas-Asas Umum Pemerintahan Yang Layak (AAUPL) di Lingkungan Peradilan Administrasi Indonesia, Citra Aditya Bakti, Bandung, 1999. , Revolusi Hukum Indonesia: Makna Kedudukan dan Implikasi Hukum

Naskah Proklamasi 17 Agustus 1945 Dalam Sistem Ketatanegaraan RI, KonPress, Jakarta, 2006.

John J.O.I. Ihalauw, Konstruksi Teori: Komponen dan Proses, Grasindo, Jakarta, 2008.

Kuntjoro Purbopranoto, Beberapa Catatan tentang Hukum Tata Pemerintah dan Peradilan Administrasi Negara, Alumni, Bandung, 1985.

Nashr Hamid Abu Zaid, Hermeneutika Inklusif: Mengatasi Problematika Bacaan dan

Cara-Cara Pentakwilan atas Diskursus Keagamaan, translated by Muhammad Mansur and Khorian Nahdliyin, Jakarta, International Center For Islam and Pluralism, 2004. 
Philipus M. Hadjon, (et.al), Pengantar Hukum Administrasi Indonesia, Gadjah Mada University Press, Yogyakarta, 2011.

Paimin Napitupulu, Pelayanan Publik dan Customer Satisfaction, Alumni, Bandung, 2014.

Ridwan HR, Hukum Administrasi Negara, RajaGrafindo Persada, Jakarta, 2006.

S. Wojowasito and W.J.S. Poerwadarminta, Kamus Lengkap: Inggris-IndonesiaIndonesia-Inggris, Hasta, Bandung, 1980.

Wahyudi Kumorotomo, Etika Administrasi Negara, RajaGrafindo Persada, Jakarta, 2001.

\section{Other Documents}

Altshuler, Fred H. "Comparing the Nixon and Clinton Impeachments", Hastings Law Journal, Vol. 51, Issue 4, 2000.

Lutfil Ansori, "Diskresi dan Pertanggungjawaban Pemerintah dalam Penyelenggaraan Pemerintahan", Jurnal Yuridis, Vol. 2, No. 1, 2015.

Genovese, Michael A. "Impeachment Revisited in the Age of Trump", Book Review Essay, Presidential Studies Quarterly, Vol. 48, Issue 3, 2018.

Halstead, T. J. "An Overview of the Impeachment Process", CRS Report for Congress Received through the CRS Web, Issue 20, April 2005.

Isenbergh, Joseph, "Impeachment and Presidential Immunity from Judicial Process," Yale Law and Policy Review, Vol. 18, Issue 53, 1999.

Eny Kusdarini, "Asas-asas Umum Pemerintahan yang Baik pada Produk Hukum Perizinan Investasi Pemerintah Daerah", Jurnal Hukum IUS QUIA IUSTUM, Vol. 24, No. 4, 2017.

M. Beni Kurniawan, "Penggunaan Diskresi dalam Pemberian Status Kewarganegaraan Indonesia terhadap Archandra Thahar ditinjau dari Asas Pemerintahan yang Baik", Jurnal Penelitian Hukum DE JURE, Vol. 18, No. 2, 2018.

Muhamad Azhar, "Relevansi Asas-Asas Umum Pemerintahan Yang Baik dalam Sistem Penyelenggaraan Administrasi Negara", NOTARIUS, $8^{\text {th }}$ Edition, No. 2, 2015.

Nadir (et.al), "Philosophical Validity, Theoretical, Normative and Empirical Paradigm of General Principles of Good Governance (AUPB) As A Review of Presidential Impeachment", Brawijaya Law Journal, Vol. 4, No. 1, 2017.

Nadir, "Dilematika Putusan Mahkamah Konstitusi vs Kekuatan Politik dalam Impeachment Presiden", Jurnal Konstitusi, Vol. 9, No. 2, 2012.

Safri Nugraha, "Aspek Hukum Administrasi Negara dalam Pelaksanaan Keputusan Pejabat Badan Hukum Publik: Telaah Akademis atas Rekening 502", article as part of Mahkamah Konstitusi Republik Indonesia with Konrad Adenauer Stiftung report on 2005. 
The Paradigm of the General Principles of Good Governance as Examination Method of Indonesian Presidential Impeachment Based on the Perspective of Ethical Control

Saikrishna Prakash, and Steven Smith D., "How to Remove a Federal Judge", Yale Law Journal, Vol. 116, Issue 1, 2006.

Rahayu Prasetianingsih, "Menakar Kekuasaan Presiden dalam Pembentukan Peraturan Perundang-undangan menurut Undang-Undang Dasar 1945", Padjadjaran Jurnal of Law, Vol. 4, No. 2, 2017.

Smith, Alexa J. "Federal Judicial Impeachment: Defining Process Due", Hastings Law Journal, Vol. 46, Issue 2, 1995.

Djodi Suranto, "The Implementation of Good Governance General Establishment and Application in The Formation of Good Governance Implementation in Indonesian National Army", Jurnal Hukum dan Peradilan, Vol. 6, No. 1, 2017.

Soetandyo Wignjosoebroto, "Hukum dan Metode-metode Kajiannya dan Penelitian Hukum: Sebuah Tipologi”, Masyarakat Indonesia Magazine, Vol. 1, No. 2, 1974.

\section{Legal Documents}

The 1945 Constitution of the Republic of Indonesia.

The Law Number 24 of 2003 on the Constitutional Court of the Republic of Indonesia (Undang - Undang Nomor 24 Tahun 2003 tentang Mahkamah Konstitusi).

The Law Number 48 of 2009 on Judge's Judicial Power (Undang - Undang Nomor 48 Tahun 2009 tentang Kekuasaan Kehakiman). 